\title{
Evaluation of Landslide Hazard Levels Post 2014 Flood Disaster in Manado City
}

\author{
$1^{\text {st }}$ Selvana Treny Rosita Tewal \\ Geography Department \\ Social Science Faculty \\ Universitas Negeri Manado \\ Manado, Indonesia \\ Selvana.tewal@gmail.com \\ $4^{\text {th }}$ Xaverius Erick Lobja \\ Geography Education Department \\ Social Science Faculty \\ Universitas Negeri Manado \\ Manado, Indonesia \\ ericklobja@unima.ac.id
}

\author{
$2^{\text {nd }}$ Helena Sri Sulastriningsih \\ Geography Department \\ Social Science Faculty \\ Universitas Negeri Manado \\ Manado, Indonesia \\ Hssulastriningsih@yahoo.co.id \\ $5^{\text {th }}$ Kalvin Salindeho Andaria \\ Geography Education Department \\ Universitas Negeri Manado \\ Manado, Indonesia \\ kalvinsa@unima.ac.id
}

\author{
$3^{\text {rd }}$ Murdiyanto \\ Geography Department \\ Faculty of Social Science \\ Universitas Negeri Manado \\ Manado, Indonesia \\ murdiyanto@unima.ac.id
}

\begin{abstract}
This study aims to study and map landslide agencies in the city of Manado in the aftermath of the 2014 Flash floods disaster. Landslide hazard mapping is based on physical factors and trigger factors for landslides. The method used is quantitative descriptors, which begins with an analysis of maps and aerial photographs, data collection is done through observation, field measurements, and laboratory analysis. Data were analyzed by means of field parameters and based on the results of the analysis showed that landslides in the city occurred due to physical factors such as slope, soil texture, soil permeability, soil solum thickness, weathering of rocks, percentage of steep walls, land use, vegetation density, outside drainage and Deep drainage in addition to the trigger factors, namely high rainfall and land use contribute to landslides. Based on the results of the analysis and mapping of landslides, in the city of Manado, there were three landslide hazard levels, namely low, moderate and high landslide hazard levels.
\end{abstract}

\section{Keyword: Terrain, landslides, hazard level maps}

\section{INTRODUCTION}

Landslides are one of the geological disasters that often occur in Indonesia, especially in the rainy season. Reference [1] states that landslides are influenced by the following controlling factors: Amount and distribution of rainfall, changes in temperature, topography, geological structure, slope, permeability and other matters related to land and rock utilization. These control factors found in Manado City where in addition to the slope varies from flat to steep, in terms of geology are composed of young volcanic rocks consisting of lava, capillary bombs, and ash where these rocks are classified as unconsolidated rocks so it is vulnerable to landslides [2].

Judging from the rainfall, the city of Manado has a high rainfall of 3473mm / year (BMG Manado 2014). In addition, in terms of physical development continues to experience proven developments from the establishment of several shopping centers, star hotels and good residential locations that are simple to luxury housing. That spurred the opening of new land even to the cutting of the hill so that it tilted the slope and all of them had an impact on Manado city against landslides.

According to the data, the landslide incident in the city of Manado in 1996 claimed 7 human lives, 2 people were seriously injured, 5 houses were buried in land and 103 houses were severely damaged Kompas February 11, 1996, Suara Pembaruan 16 February 2016 later, in 2013 landslide events claimed 1 fatality, Manado Tribune January 3, 2013, and the landslide incident in February 2013 claimed 19 lives Metro February 16, 2013. The increasing number of casualties due to landslides is certainly important to find a solution to minimize the risk caused by landslides, especially with the occurrence of disasters Flash floods in Manado City January 2014 this certainly contributes to landslide conditions in the city of Manado because rainfall is one of the factors triggering landslides.

Research on landslides has been carried out by several researchers including Novia, Adjie, 2013 identifying vulnerable areas of landslides in relation to communities in Sleman Regency, the parameters examined are environmental vulnerability, physical vulnerability and social vulnerability research results in the form of maps of physical vulnerability, social vulnerability and environmental vulnerability.

Reference [3] analyzed the risk of landslides in Tieng Kejajar Village, Wonosobo District, with parameters of rain, slope, geology, presence of faults, depth of soil, infra structure and density of settlements, results of low, medium and high landslide hazard zoning maps. . Both previous landslide studies, have similarities in several respects with this study that both use GIS techniques to produce maps, but the difference with this research is in terms of location, parameters and number of parameters examined in this case, especially soil texture parameters, soil permeability, external and internal drainage and steep wall percentages that are not included in the parameters of previous studies. This study focuses on physical factors and trigger factors for landslides in Manado City.

Map and photo analysis methods, field measurements and laboratory analysis were used in this study because to determine the landslide hazard class and the preparation of 
landslide hazard maps in the city of Manado must go through these processes.

The formulation of the research problem is how the level of landslide hazard in Manado City after the January 2014 flash flood disaster

This study aims to study and map the amount of landslide hazard in the city of Manado post flash flood in January 2014.

\section{RESEARCH METHODS}

This research method includes map analysis, aerial photo interpretation, observation, field measurements and laboratory analysis. Data analysis was carried out with respect to field unit parameters.

As the object of this research is a landslide that is defined as the movement of soil and rocks due to disturbance to slope stability, while the subject of the research is the people of Manado City. Prepare basic data in the form of geological maps, earth map, aerial photographs for interpretations. In order to compile geomorphological maps, land use maps, temporary terrain maps. Analysis of the earth map to accommodate the slope map. Map making of field units for the design of determining sample points in the field. Data retrieval measurement data: slope, drainage, texture, permiability, thickness of soil solum, weathering of rocks, percentage of steep walls, land cover, vegetation density. Annual secondary data collection in the form of temperature data, rainfall at Meteorology and Geophysics stations. Sampling of soil samples at each sample point. Laboratory analysis of soil texture and permiability, tabulation, classification and data analysis by scoring against field parameters. The terrain of each field meter is referring to the following guidelines.

\section{RESULTS AND DISCUSSION}

Table 1 Due to slope grade

\begin{tabular}{|l|l|l|l|l|}
\hline No & Class & \multicolumn{1}{|c|}{ Big Slope } & \multicolumn{1}{|c|}{$\begin{array}{c}\text { Slope } \\
\text { criteria }\end{array}$} & quality \\
\hline 1 & I & $0-8 \%$ & Flat & 1 \\
2 & II & $>8 \%-15 \%$ & Sloping & 2 \\
3 & III & $.15 \%-25 \%$ & Sloping & 3 \\
4 & IV & $.25-40 \%$ & Steep & 4 \\
5 & V & $>40 \%$ & Very steep & 5 \\
\hline
\end{tabular}

Source: reference [4]

Table 2 Class quality of Soil Texture

\begin{tabular}{|c|l|c|}
\hline No & Class Texture & Quality \\
\hline 1 & Loam & 1 \\
2 & The melancholy, the thud & 2 \\
3 & Dark sand & 3 \\
4 & Sandstone clay, debris clay & 4 \\
5 & Clay, sand & 5 \\
\hline
\end{tabular}

Source: reference [5]

Data analysis in determining the landslide hazard class using the formula:
$\mathrm{I}=(\mathrm{c}-\mathrm{b}) / \mathrm{k}$

where: $\mathrm{I}=$ Large class range

$\mathrm{b}=$ the lowest number of digits

$\mathrm{c}=$ Number of highest prices

$\mathrm{k}=$ number of classes desired [4]

The number of variables used is 10 so the lowest level is 10 and the highest level is 50 , then based on the formula, the range of each class of landslide hazard if it is made into 5 classes is as follows: $(50-10) / 5=40 / 5=8$.

Classification of landslide hazard class results as shown in the following table:

Table 3. Landslide Hazard Classes

\begin{tabular}{|c|c|c|c|}
\hline No & Total score & $\begin{array}{c}\text { Landslide Hazard } \\
\text { Class }\end{array}$ & Criteria \\
\hline 1 & $10-17$ & I & Very low \\
\hline 2 & $18-25$ & II & Low \\
\hline 3 & $26-33$ & III & Medium \\
\hline 4 & $34-41$ & IV & High \\
\hline 5 & $42-50$ & V & Very high \\
\hline
\end{tabular}

Based on the value of the ten field parameters, it can be explained that the landslide hazard class in the study area is affected by ten field parameters and the ten parameters mentioned which give a substantial contribution to landslides is the permeability of the soil, because the slow permeability of the soil affects the slow passage of water into the soil and this condition can be seen from the presence of inundation after rain, besides vegetation density the denser the vegetation is difficult to landslide but because the study area is a urban settlement area where vegetation density is very rare. The soil layer in the study area also supports landslides because generally the soil layer is thick where a thick layer of soil will store more water than a thin soil solution. At certain locations the slope contributes quite high. In addition, rainfall and land use factors also trigger landslides in Manado City. Based on the results of an analysis of landslide field parameters in the city of Manado, the three categories of hazard levels were reduced, namely low landslide hazard levels, moderate landslide hazards and high landslide hazards. Low hazard level with 5 field units, moderate hazard level with 18 field units, and high landslide hazard level with 2 field units thus dominating in the study area is the moderate landslide hazard level. The landslide hazard level in the study area is shown through the landslide hazard level map in Figure 1 below. 


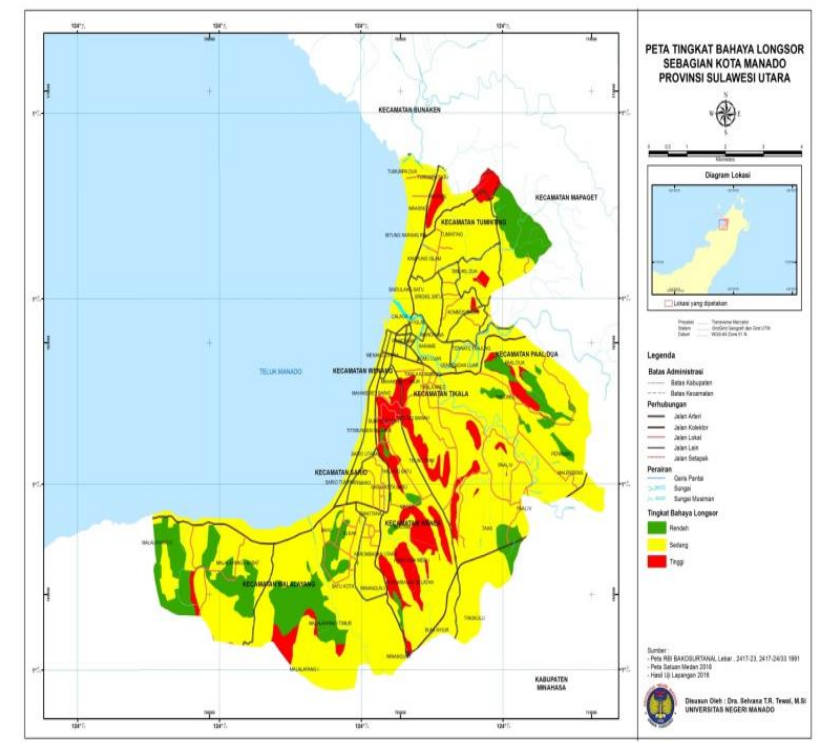

\section{CONCLUSION}

Based on the results of research on the level of landslide hazard in the study area, there were three categories of hazard levels namely low landslide hazard level, moderate landslide hazard level and hazard level.

\section{ACKNOWLEDGMENT}

The author would like to say thank Dean of Social Science Faculty Manado State University.

\section{REFERENCES}

[1] Q. Zaruba and V. Mencl, Landslides and their control, vol. 31. Elsevier, 2014

[2] Effendi, Peta Geologi Bersistem, Lembar Manado 2416 dan 2417. Jakarta: Direktorat Geologi Departemen Pertambangan RI.

[3] E. M. Astuti and W. Djarot Sadharto, "Analisis Risiko Tanah Longsor Desa Tieng Kecamatan Kejajar Kabupaten Wonosobo.” Universitas Gadjah Mada, 2011.

[4] S. Dibyosaputro, "Longsorlahan Di Daerah Kecamatan Samigaluh, Kabupaten Kulon Progo, Daerah Istimewa Yogyakarta," Maj. Geogr. Indones., vol. 16, no. 2, pp. 13-34, 2016.

[5] S. Arsyad and E. Rustiadi, Penyelamatan tanah, air, dan lingkungan. Yayasan Pustaka Obor Indonesia, 2008. 